\title{
Yumurta Tavukçuluğu İşletmeleri: Hatay İli Örneği
}

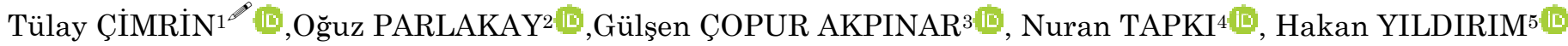

${ }_{1,3,5}$ Hatay Mustafa Kemal Üniversitesi Ziraat Fakültesi Zootekni Bölümü, Hatay, ${ }^{2,4}$ Hatay Mustafa Kemal Üniversitesi Ziraat Fakültesi Tarım Ekonomisi Bölümü Hatay

${ }^{1}$ https://orcid.org/0000-0002-5868-4148, ${ }^{2}$ https://orcid.org/0000-0001-6012-0723, ${ }^{3}$ https://orcid.org/0000-0003-1907-8855,

${ }^{4}$ https://orcid.org/0000-0001-5044-795X, ${ }^{5}$ https://orcid.org/0000-0003-3480-6013

$\bowtie:$ tcimrin@hotmail.com

\section{ÖZET}

$\mathrm{Bu}$ çalışma ile Hatay ilinde yumurta tavukçuluğunun durumu incelenmiştir. Çalışmanın ana materyalini Hatay ilinde üretim yapan 23 yumurta tavukçuluğu işletmesinden tam sayım yöntemiyle yüz yüze yapılan anketlerle elde edilen veriler oluşturmuştur. Elde edilen bulgulardan, üreticilerin yaş ortalaması 44 yıl olup, \%75'inden fazlasının 1-5 yıl arası deneyime sahip olduğu belirlenmiştir. İşletmelerin kurulu kapasite ortalaması 4627 adet olup, yaklaşık yarısı (\%47.83) işletme kapasitesinin tamamını kullanmaktadır. Ayrıca işletmelerin \%73.91'i tek bir kümesten oluşmakta ve \%86.96'sı kullandığı yemi satın alarak üretim yapmaktadır. İşletmelerin yarısından fazlası işgücü ihtiyacını işletme dışından karşılamaktadır. İşletmecilerin 2/3'si kullandığı yarkaları il dışından temin ederken, yarısından fazlası yerli genotip olan Atak-S ırkını tercih etmektedir. Kalifiye işçi yetersizliği, yem ve yem hammadde fiyatlarının yüksek olması, yumurta satış fiyatlarının düşük olması, fiyat istikrarsızlığı, yarka temin etme güçlüğü ve üreticiler arasında birlik olmaması bölgedeki işletmelerin temel sorunlarıdır. $\mathrm{Bu}$ sorunları çözmek için yetiştiricilerin yem, yarka ve pazarlamaya yönelik sorunları ele alması gerekmektedir.

\section{Egg Production Enterprises The example of Hatay Province}

\section{ABSTRACT}

In this study, the status of egg poultry in Hatay province was investigated. The main material of the study was the data obtained from face-to-face questionnaires by the full counting method from the 23 poultry enterprises producing eggs in Hatay province. The data obtained indicated that the average age of the producers was 44 years. It has been determined that more than $75 \%$ of producers have 1-5 years of experience. The installed capacity average of the businesses was 4627 . Also, it was determined that approximately half of the enterprises were using the total production capacity. In addition, $73.91 \%$ of the enterprises with a single coop and $86.96 \%$ of the feed was used by purchasing. More than half of the enterprises provide labor permanently. While the layers used are supplied from out of the Hatay Province, more than half of them use Atak-S, which are native genotypes. Two-thirds of the enterprises that are preparing their own rations were continuing their production by receiving external technical support for preparing rations. The main problems of the enterprises in the region were the lack of qualified workers, the high feed and feedstock prices, the low and unstable egg sales prices and the difficulty in obtaining the pullet. In order to solve these problems, it is necessary to raise the awareness of farmers about feed, pullet and marketing.

\section{Araştırma Makalesi}

Makale Tarihçesi

Received: 04.03.2019

Accepted: 09.05.2019

\section{Anahtar Kelimeler}

Genotip

Sorunlar

Yumurta tavukçuluğu

Yem temini durumu

\section{Research Article}

\section{Article History}

Geliş : 04.03.2019

Kabul : 09.05.2019
Keywords
Genotype
Problems
Egg poultry
Feed supply status

To Cited : Cimrin T, Parlakay O,Çopur Akpınar G, Tapkı N, Yıldırım H 2019. Yumurta Tavukçuluğu İşletmeleri: Hatay İli Örneği. KSÜ Tarim ve Doğa Derg 22(5): 787-793, DOI: 10.18016/ksutarimdoga.vi.535149. 


\section{GİISŞ}

Yumurta insanların protein ihtiyacını karşılayan önemli besin kaynaklarından biridir. Kolay ve ucuz bulunabilir olması, orta ve dar gelirli ailelerin beslenmesi yönünden büyük önem taşımaktadır. Yumurta üretim maliyetinin göreceli olarak düşük olması nedeniyle üretim ve tüketim açısından diğer hayvansal üretim kollarına göre daha avantajlı olduğu söylenebilir (Şahin ve Yıldırım, 2001). Canlı materyal ile üretim yapılması yumurta sektörünün en önemli özelliğidir. Yumurta üretimine başlama süresi $4.5-5$ aylık bir zaman almasına karşın üretim döneminde arz-talep dengesini oluşturmak zor olmaktadır (Anonim, 2019a). Arz-talep dengesi; mevsimsel nedenler, ihracat miktarı ve bazen de piyasada ortaya çıkan spekülasyonlardan çok hızlı etkilenmektedir. Öte yandan yumurtanın pazarda kalma süresi 28 gün gibi çok kısa bir periyottur ve bu sürede yumurtanın çok hızlı bir şekilde pazarlanması gerekmektedir. Yumurtanın depolanma süresi sınırlı ve sıkıntılıdır. Türkiye'de yumurta ürünleri sanayii henüz gelişme aşamasındadır. Yumurta sektörünün en önemli avantajı ise peşin veya kısa vadeli satışlarla nakit akışının hızlı olmasıdır (Anonim, 2019b).

Aydın ve Çelen (2017) 2014 yılı istatistiklerine göre (Anonim, 2014) GAP Bölgesindeki 32 kümesten oluşan 18 yumurtacı işletmede üretilen toplam yumurta sayısının 1.547.000 olduğunu bildirmişlerdir.

Türkiye'de son yıllarda yumurta tavuğu sayısında artış olduğu gözlenmiştir. 2010 yılında 70.933 .660 adet olan mevcut sayı 2018 yıl sonu itibariyle 127.372.689 adet olarak gerçekleşmiştir (Anonim 2018a). 2015 yılında Dünya yumurta üretiminde ilk 9. sırada yeralan Türkiye, Dünya yumurta ihracaatı sıralamasında üçüncüdür. Türkiye'nin 2018 yılı itibariyle 22.3 milyar adet olan ticari yumurta üretiminin \%25.92'si ihraç edilmiştir (Anonim, 2019b). Hatay ili yumurta tavuğu sayısı 2010 yılında 376.880 adet iken 2016 yılında bu sayı 530.126 adet olarak bildirilmiştir (Anonim, 2018b).

Çalışmada Hatay ilinde yumurta tavukçuluğunun gerek işletme gerekse işletmeciler ile ilgili bazı özelliklerinin ele alınarak mevcut durumunun ortaya konulması amaçlanmıştır. Hatay ili için ilk defa yapılan bu çalışma, il ve bölgede faaliyette bulunan ya da bulunacak olan üreticilere ışık tutması yanında, tecrübeli üreticilerin bilgi birikiminin genç üreticiler ile paylaşılmasında katkı sağlayacaktır. Ayrıca çalışma, bölgede tavukçuluk yapan üreticilerin sorunları ve çözüm önerilerinin değerlendirilmesi açısından temel bir kaynak olacaktır.

\section{MATERYAL ve METOT}

Yumurta tavukçuluğu yapan işletmelerin mevcut durumunun ortaya konulması amaciyla yapilan bu çalışmanın ana materyalini Hatay ilinde üretim yapan tavukçuluk işletmelerinden elde edilen veriler oluşturmaktadır. Çalışmanın yapılacağı işletmelerin tespit edilmesi aşamasında; Hatay İ Tarım ve Orman Müdürlüğü Hayvan Sağlığı ve Yetiştiriciliği Şube Müdürlüğü kayıtlarından faydalanılmıştır. İldeki toplam tavukçuluk işletme sayısı, işletmelerin ilçe ve mahallelere göre dağılımları belirlendikten sonra, işletme sayısının örnekleme yapmaya yeterli olmayacak düzeyde olması nedeniyle veriler tam sayım yöntemiyle toplanmıştır. Toplam 23 adet yumurta tavukçuluğu işletmesinden veri alınmıştır. Verilerin toplanmasında yüzyüze anket yöntemi kullanılmıştır. Hazırlanan anket formları sözü edilen işletmelerde uygulanarak anket aşaması tamamlanmıştır. Konuyla ilgili önceden yapılmış tezler, makaleler, rapor vb çalışmalar ile Türkiye İstatistik Kurumu'ndan elde edilen yardımcı materyallerden faydalanılmıştır. Veriler analiz edilmeden önce standart hale getirmek için aynı birimlere çevrilmiş ve analize hazır hale getirilmiştir. Verilerin analizinde frekans tabloları ve yüzde hesaplamalar kullanılmıştır. Elde edilen veriler tablolar halinde özetlendikten sonra, işletme ve işletmecilerin profili incelenmiştir. Üreticilerin demografik özellikleri ile işletme yapısı incelenerek yumurtacı tavuk işletmelerinin mevcut durumu ortaya konulmuştur.

\section{BULGULAR ve TARTIŞMA}

Hatay ilinde yumurta tavukçuluğu yapan işletmelerin kapasite özelliklerine ait veriler Çizelge 1'de özetlenmiştir. Hatay ilindeki yumurta tavukçuluğu işletmelerinin yarısından fazlasının (\%52.17) 2015 yılından sonra kurulduğu görülmektedir (Çizelge 1). $\mathrm{Bu}$ bulgular, son yıllarda işletme kuruluşu için verilen desteklerin (Tarım ve Orman Bakanlığı, KOSGEB vs.) etkili olduğunu göstermektedir. İşletmelerde kurulu kapasite düzeyi ortalama 4557 adet olarak hesaplanırken, işletmelerin \%78.26'sının 5000 adetin altında kurulu kapasiteye sahip olduğu belirlenmiştir. Alagöz (1983), Çukurova yöresinde yaptığı çalışmada yumurta tavukçuluğu işletmelerinin \%73.9'unda kapasitenin 6.000 adedin altında olduğu belirtilmiştir. $\mathrm{Bu}$ görünümü ile Hatay ilindeki işletmelerin kapasite itibarıyla küçük ölçekli olduğunu söylemek mümkündür.

İşletmelerin yaklaşık \%82.61'inin 5000 adete kadar yumurta tavuğu kapasitesine sahip olduğu görülmüştür. İşletmelerin \%69.57'inin mevcut kapasitelerinin \%81'inden fazlasını kullandıkları ve kapasite kullanım düzeyinin yaklaşık 3645.87 adet olduğu belirlenmiştir. Hatay ili genelinde \%84.43 hesaplanan işletmelerin kapasite kullanım oranı, Çorum ilinde tesbit edilen \%72.38 değerinden yüksek (Bayaner, 1999), \%83.0 değerine (Efil ve ark., 1993) ise oldukça yakın bulunmuştur. 
Çizelge 1. Hatay ilinde yumurta tavukçuluğu işletmelerinin kapasite özellikleri

\begin{tabular}{|c|c|c|c|c|}
\hline & Gruplar & Adet & $(\%)$ & Kümülatif \\
\hline \multirow{3}{*}{ Kuruluş yılı } & 2010 öncesi & 3 & 13.04 & 13.04 \\
\hline & 2010-2015 arası & 8 & 34.78 & 47.82 \\
\hline & 2015 sonrası & 12 & 52.17 & 99.99 \\
\hline \multirow{6}{*}{ Kurulu kapasite } & $<1000$ adet & 4 & 17.39 & 17.39 \\
\hline & $1000-2000$ adet & 8 & 34.78 & 52.17 \\
\hline & 2001-5000 adet & 6 & 26.09 & 78.26 \\
\hline & $>5000$ adet & 5 & 21.74 & 100.00 \\
\hline & Toplam & 104.800 & & \\
\hline & Ortalama & 4556.52 & & \\
\hline \multirow{6}{*}{ Kullanılan kapasite } & $<1000$ & 6 & 26.09 & 26.09 \\
\hline & $1000-2000$ & 9 & 39.13 & 65.22 \\
\hline & $2001-5000$ & 4 & 17.39 & 82.61 \\
\hline & $>5000$ & 4 & 17.39 & 100.00 \\
\hline & Toplam & 83.855 & & \\
\hline & Ortalama & 3645.87 & & \\
\hline \multirow{4}{*}{ Kapasite kullanım oranı } & $\% 1-\% 50$ arası & 3 & 13.04 & 13.04 \\
\hline & $\% 51^{-\%} \% 80$ & 4 & 17.39 & 30.43 \\
\hline & $\% 81$ ve üzeri & 16 & 69.57 & 100.00 \\
\hline & Ortalama & $\% 84.43$ & & \\
\hline \multirow{3}{*}{ Kümes sayısı } & 1 & 17 & 73.91 & 73.91 \\
\hline & 2 & 5 & 21.74 & 95.65 \\
\hline & 5 & 1 & 4.35 & 100.00 \\
\hline
\end{tabular}

Cönk (2006) Afyonkarahisar'da yumurta tavukçuluğu yapan işletmelerin \%44.4'ünün kapasitelerinin \%80'ninden fazlasının kullandığını belirlemiştir. Ayrıca, işletmelerde ortalama kurulu kapasitenin 72.074 adet, ortalama kullanılan kapasitenin ise 47.898 adet olduğunu tespit etmiştir. Tüm işletmeler bazında kapasite kullanım oranını \%66.46 olarak belirlemiştir. Köse ve Durmuş (2014), Ordu'da kurulu tavukçuluk işletmelerinin toplam kapasitelerinin 311.800 adet olduğunu ve bunun \%80.4'ünün kullanıldığını belirlemişlerdir. Çicek ve ark. (2008) ise kapasite kullanım oranını \%64.01 olarak belirlemişlerdir. Yine farklı bir çalışmada, Şahin ve Yıldırım (2001) Van ilinde faaliyet gösteren üç yumurta tavuğu işletmesinde kapasite kullanım oranını \%70.08 olarak belirlemişlerdir. Mevcut çalışmada ise Hatay ilinde toplam kurulu tavukçuluk işletme kapasitesi 104.800 adettir. Kullanılan kapasite ise 83.855 adet olup, kapasite kullanım oranı ortalama \%84.43 olarak belirlenmiştir. Bu çalışmada tavukçuluk işletme kapasite kullanım oranı daha önceden yapılan diğer çalışmalarda (Şahin ve Yıldırım, 2001; Cönk, 2006; Çiçek ve ark., 2008; Köse ve Durmuş, 2014) elde edilen oranlardan daha yüksek bulunmuştur. Bu sonuç Hatay'da faaliyet gösteren işletmelerin kurulu kapasitenin düşük olması nedeniyle kapasitelerini daha iyi kullandığını ve yumurta talebinin karşlanabilmesi için kapasite kullanımının arttırması gerektiğini ortaya koymaktadır. Çalışmadan elde edilen bulgular işletmelerin kurulu kapasitelerini arttırabilecek potansiyele sahip olduğunu ortaya koymaktadır. İşletmelerin önemli bir kısmının (\%73.91) bir kümese sahip olduğu, geri kalan kısmın \%21.74'ünde iki kümes bulunduğu ve sadece bir işletmede (\%4.35) beş kümesin olduğu belirlenmiştir (Çizelge 1). Bu bulgulardan işletmelerin büyük bir kısmının küçük ölçekli işletme olduğu anlaşılmıştır.

Hatay ilinde yumurta tavukçuluğu işletmelerinin yem temin ve hammadde kullanım özellikleri Çizelge 2'de verilmiştir.

İşletmelerin sadece \%8.7'sinin kendi yemini ürettiği, yaklaşık \%87'sinin ise kullandığı yemi satın aldığı belirlenmiştir (Çizelge 2). Yumurta tavukçuluğu işletmelerinin masraflarının büyük çoğunluğunu yem masrafları oluşturmaktadır. Büyük ölçekli işletmeler yemi kendisi üretmekte iken küçük kapasiteli işletmelerin yemi dışarıdan temin ettiği bilinmektedir. Bu sebeple Hatay ilindeki küçük ölçekli işletmelerin küçük kapasiteli olması nedeniyle işletmelerin sadece \%8.7'si kendi yemini üretme yoluna gitmişlerdir (Şekil 1). Ayrica kullanılacak yemin hammadde tercihinde, işletmecilerin \%61'i hayvanların ihtiyacını, \%26'sı ise üretilecek ürünün niteliğini göz önünde bulundurduğunu ifade etmişlerdir. Yine işletmecilerin yaklaşık \%65’i dışarıdan aldıkları yem için ayrıca katkı maddesi kullanmamaktadır. İşletmelerde kullanılan işgücü sayısı ortalama 2.3 olarak hesaplanırken, işletmelerin yaklaşık \%60'ı işgücü ihtiyacını daimi işgücünden karşılamaktadır. Oysa Şahin ve Yıldırım (2001) ortalama kapasitesi 17.700 olan işletmelerde çalışan sayısı ortalamasını 5.3 kişi 
(erkek iş birimi) olarak bildirmişlerdir.

İşletmeler arasında yumurta başlangıç yaşı ve pik yaşı ile ilgili farklılık saptanmamıştır. Hatay ilinde faaliyet gösteren işletmeler genellikle küçük olduğu için yumurtaya başlama dönemindeki birkaç günlük farklılıklar önemsenmemiştir. İşletmecilerin en az 2/3'si yarkaları il dışından (Ankara, Konya ve Mersin) temin etmektedir (Çizelge 3).

Çizelge 2. Hatay ilinde yumurta tavukçuluğu işletmelerin yem, hammadde ve iş gücü özellikleri

\begin{tabular}{llrr}
\hline & & Adet & $(\%)$ \\
\hline \multirow{2}{*}{ Yem temin durumu } & Kendi yemini yapıyor & 2 & 8.70 \\
& Yem fabrikasından alıyor & 20 & 86.95 \\
& Piyasadan alıyor & 1 & 4.35 \\
\hline \multirow{2}{*}{ Yem hammadde seçimi } & Hayvanın ihtiyacına göre & 14 & 60.87 \\
& Fiyatına göre & 2 & 8.70 \\
& Uretilecek ürün niteliğine göre & 6 & 26.09 \\
& Diğer & 1 & 4.35 \\
\hline \multirow{2}{*}{ Yem hammadde kullanım düzeyi } & Sahibim & 4 & 17.39 \\
& Sahip değilim & 19 & 82.61 \\
\hline \multirow{2}{*}{ Yem katkı maddesi kullanımı } & Evet & 8 & 34.78 \\
& Hayır & 15 & 65.22 \\
\hline Yem ünitesi durumu & Var & 3 & 13.04 \\
& Yok & 20 & 86.96 \\
\hline \multirow{2}{*}{ İ̧ücü kaynağı } & Kendisi & 9 & 39.13 \\
& Daimi işçi & 14 & 60.87 \\
\hline
\end{tabular}

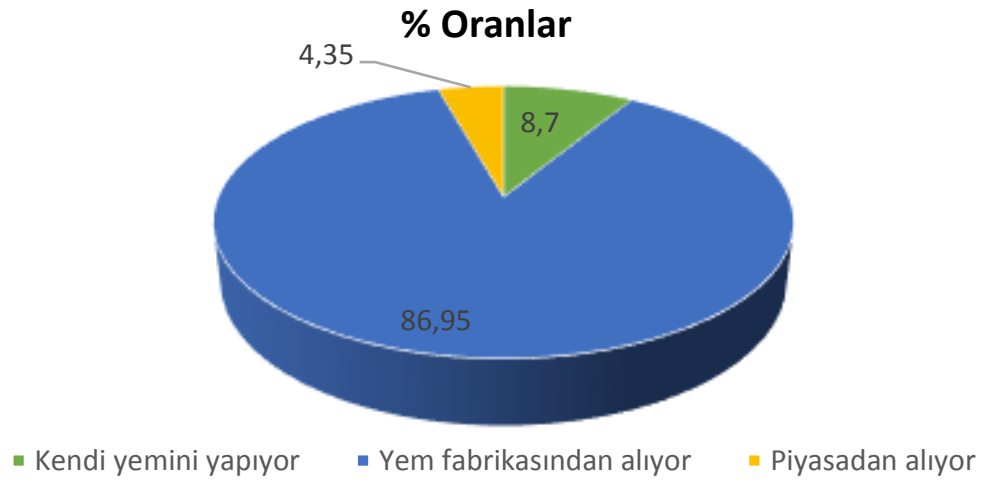

Şekil 1. İşletmelerin yem temin durumlarının dağılımı

Çizelge 3. Hatay ilindeki işletmelerin yumurtacı tavuklarla ve yumurta üretimi ile ilgili bazı özellikleri

\begin{tabular}{|c|c|c|c|}
\hline \multirow[t]{2}{*}{ Yumurta başlangıç ve pik yaşı } & $\begin{array}{l}\text { Başlangıç (Hafta) } \\
\text { Pik verim (Hafta) }\end{array}$ & $\begin{array}{l}20 \\
32 \\
\end{array}$ & \\
\hline & & Adet & $(\%)$ \\
\hline \multirow{4}{*}{ Yarka temin yeri } & Ankara & 7 & 30.43 \\
\hline & Konya & 6 & 26.09 \\
\hline & Mersin & 2 & 8.70 \\
\hline & Diğer & 8 & 34.78 \\
\hline \multirow{3}{*}{ Kullanılan hibritler } & Atak-S & 12 & 52.17 \\
\hline & Lohman & 3 & 13.04 \\
\hline & Nick-Brown & 8 & 34.78 \\
\hline \multirow{2}{*}{$\begin{array}{l}\text { Yumurta kod ve paketleme } \\
\text { makinesi }\end{array}$} & Var & 4 & 17.39 \\
\hline & Yok & 19 & 82.61 \\
\hline \multirow{4}{*}{ Yillık yumurta üretimi } & $0-500.000$ adet & 12 & 52.17 \\
\hline & $501.000-1.000 .000$ & 6 & 26.09 \\
\hline & $1.000 .001-2.000 .000$ & 2 & 8.70 \\
\hline & 2.000.000 üzeri & 3 & 13.04 \\
\hline
\end{tabular}




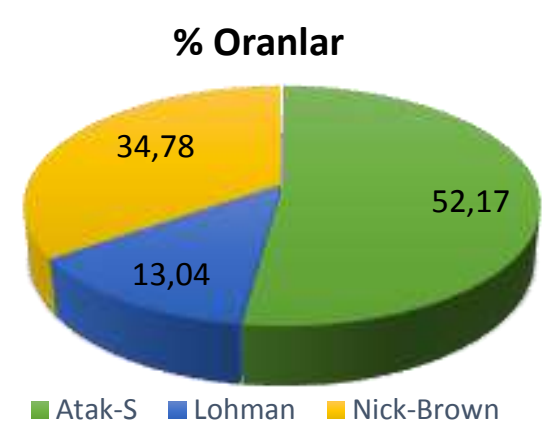

Şekil 2. İşletmelerin kullandığı hibrit genotiplerinin dağılımı

Hatay ilinde yarka ve yumurtacı civciv üretimi yapan firma bulunmamaktadır. Eleroğlu ve ark. (2004), yumurta üretimine yönelik olarak kurulmuş damızlık işletmelerin piyasaya yarka ve yumurtacı civciv verdiğini rapor etmişlerdir. İşletmelerin yaklaşık \%52.18'i de yerli genotip olan Atak-S ırkını, \%47.82'si de Lohman ve Nick-Brown gibi yabancı kaynaklı hibritleri kullanmaktadır. Demircan ve ark. (2016) Afyon ilinde kullanılan hibrit genotiplerin \%75'inin Lohmann, Nick Chick, Bovans White, \%25'inin ise $\mathrm{Hy}^{-}$ Line, Brown Nick olduklarını belirtmişlerdir. Hatay bölgesinde olumsuz çevre koşullarına daha dayanıklı ve serbest dolaşıma elverişli olan yerli genotip Atak-S ırkı tavukların daha çok tercih edildiği görülmüştür (Şekil 2).

İsletmelerin yaklaşık \%17'si yumurta kod ve paketleme makinesine sahipken, \%82.61'inde kod ve paketleme makinesi bulunmamaktadır. Bunun yanında Aydın ve Çelen (2017), Gap bölgesinde ki tüm işletmelerin bir yumurta tasnif ve paketleme ünitesine sahip olduğunu ve bu ünite varlıklarının işletmelerin üretim kapasitelerine bağlı olarak değiştiğini ifade etmişlerdir. Hatay ilinde faaliyet gösteren işletmelerin yaklaşık 1/5'inde kot ve paketleme ünitesinin olmaması kurulu kapasitenin düşüklüğü ve üretim maliyetinin yüksekliği ile ilişkilendirilebilir. Üreticilerin \%52.17'sinin 500.000 ve altında yumurta üretirken, \%47.83'ünün yıllık 500.000 adetten fazla yumurta ürettiği görülmektedir (Çizelge 3). Bu sonuçlar işletmelerin yarısından fazlasının küçük miktarda yumurta üreten işletme olduğunu göstermektedir. Nitekim YUM-BIR verilerine göre 2018 yılında Hatay ilinde faaliyet gösteren ve bir kümese sahip olan 11 işletmenin 8 adetinin küçük işletme olduğu rapor edilmiştir (Anonim. 2019c).

Hatay ilinde yumurta tavukçuluğu yapan üreticilerin demografik özellikleri Çizelge 4’te verilmiştir.

Araştırma yapılan üreticilerin demografik özellikleri incelendiğinde; yaklaşık \%61'inin erkek, \%39'unun ise kadın olduğu görülmüştür (Çizelge 4). Kadın üretici sayısının artış göstermesine neden olarak, son yıllarda verilen desteklerde prosedür açısından kadınların daha avantajlı olması gösterilebilir.

Çizelge 4. Hatay ilinde yumurta tavukçuluğu yapan üreticilerin demografik özellikleri

\begin{tabular}{llrr}
\hline Demografik Özellikler & Gruplar & Adet & $(\%)$ \\
\hline Cinsiyet & Kadın & 9 & 39.13 \\
& Erkek & 14 & 60.87 \\
\hline \multirow{4}{*}{ Yaş } & $18-25$ & 2 & 8.70 \\
& $26-35$ & 4 & 17.39 \\
& $36-50$ & 9 & 39.13 \\
& 51 ve üzeri & 8 & 34.78 \\
& Toplam & 23 & 100.00 \\
Eğitim & Ortalama (yıl) & 44.26 & 4.35 \\
& Okur-yazar & 1 & 34.78 \\
& Ilkokul & 8 & 8.70 \\
& Ortaokul & 2 & 21.74 \\
& Lise & 5 & 30.43 \\
& Üniversite & 7 & 100.00 \\
\hline \multirow{5}{*}{ Deneyim (Yll) } & Toplam & 23 & 82.60 \\
& $1-5$ & 19 & 8.70 \\
& 6 - 10 & 2 & 8.70 \\
& $10+$ & 2 & 100.00 \\
\hline
\end{tabular}


Bu desteklerin amacının Türkiye'de kadınların üretim payı içerisindeki yüzdesini artırmak ailesine ve ülke ekonomisine katkı sağlayan kadın işletmecilerin sayısını artırmak olduğu sanılmaktadır. Nitekim Hatay İl Tarım ve Orman Müdürlüğü Hayvan Sağlığı ve Yetiştiriciliği Şube Müdürlüğü kayıtlarına göre son üç yılda (2016, 2017 ve 2018) Hatay ili kapsamında verilen Genç Çiftçi Hibe desteği sırasıyla 5 kadın 2 erkek; 4 kadın 4 erkek; 4 kadın 1 erkek olarak kayıtlara geçmiştir. İşletmecilerin yaklaşık \%40'ının 36-50 yaş aralığında, \%35'inin 51 yaş ve üzerinde olduğu görülmüştür. Cönk (2006) ise yaptığı çalışmada işletmecilerin yaklaşık \%42.6'sının $36-50$ yaş aralığında olduğunu \%50'sinin ise 51 ve üzeri yaş aralığında olduğunu bildirmiştir.

İşletmecilerin yaklaşık \%35'inin ilkokul, \%30'unun ortaokul-lise ve \%30'unun ise üniversite mezunu olduğu görülmüştür (Şekil 3). Cönk (2006), işletmecilerin yaklaşık \%33’ünün ilkokul, \%61'inin ortaokul-lise, \%6'sinm ise üniversite mezunu olduğunu belirtmiştir. Köse ve Durmuş (2014) Ordu ilinde yaptıkları çalışmada işletme sahiplerinin \%31.5'inin ilkokul, \%58'sinin ortaokul-lise, \%10.5'inin ise üniversite mezunu olduğunu belirlemişlerdir.

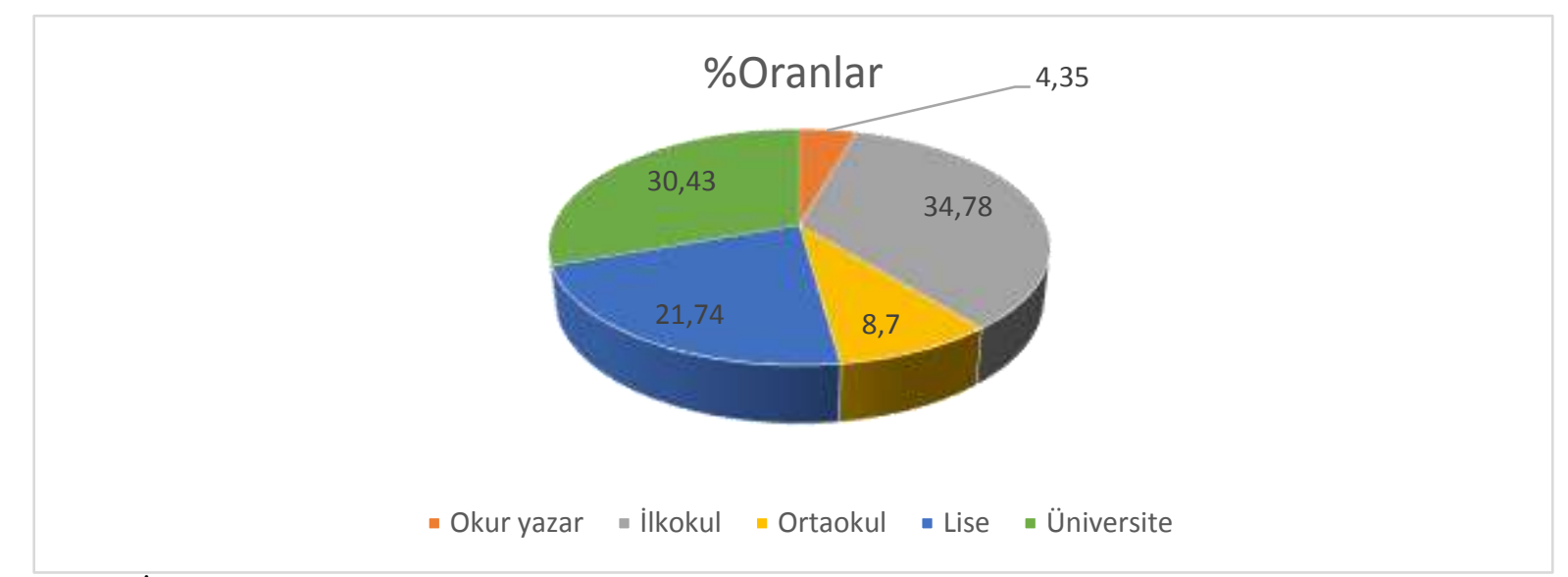

Şekil 3. İşletme sahiplerinin eğitim düzeylerinin dağılımı

Aydın ve Çelen (2017) yılında Gaziantep, Diyarbakır, Şanlıurfa Batman, Adıyaman, Kilis ve Mardin illerinde yaptıkları çalışmada işletme sahiplerinin ilkokul, lise veya üniversite mezunu olduğu, Batman'daki işletme sahiplerinin hepsinin ilkokul, Gaziantep ilindeki işletme sahiplerinin ise hepsinin üniversite mezunu olduğunu belirlemişlerdir. $\mathrm{Bu}$ çalışmada Hatay ilindeki işletmecilerin eğitim seviyeleri oransal olarak ilkokul, lise ve üniversite mezunları arasında benzer dağılım göstermiştir.

İşletmecilerin deneyimleri incelendiğinde, yaklaşık \%83'ü 1-5 yıl arasında olduğu görülmektedir. Bunun nedeninin son yıllarda uygulanan teşviklerin sektöre yeni işletmeciler kazandırmasından kaynaklandığı düşünülmektedir

Elde edilen bulgulardan Hatay ilindeki üretici profilinin orta yaşlı, sektöre yeni girmiş, yaklaşık üçte birinin ilkokul, üçte birinin ise üniversite mezunlarından oluştuğu görülmüştür. Bu profile sahip üretici ile Hatay ilinde yumurta tavukçuluğu sektörünün gelişmesinin önünün açık olduğunu söylemek mümkündür. Keza 1-5 yıl deneyime sahip olan işletmecilerin oranının yüksek olması sektördeki işletme sayısının artı̧̧ında son yıllarda canlılığın olduğunun bir göstergesi olarak kabul edilebilir. Ayrıca işletmelerin kapasitelerinin yaklaşık \%87'sini kullanmaları bu işletmeler için olumlu sonuçlardır.
Ayrıca işletmeler bir kümesle üretim yapıp, kullandığı yemi satın almaktadır. Kullanılacak yem hammaddesi tercihinde genellikle hayvanların ihtiyacı ve üretilecek ürünün niteliği dikkate alınmaktadır. İşletmelerin yarısından fazlası işgücü ihtiyacını işletme dışından daimi işgücünden karşılamaktadır. İşletmecilerin 2/3'si kullandığı yarkaları il dışından (Ankara, Konya ve Mersin) temin ederken yarısından fazlası yerli genotip Atak-S ırkı tavukları kullanmaktadır. Ayrıca Lohman ve Nick-Brown kullanılan diğer hibrit rrklardır.

\section{SONUÇ ve ÖNERİLER}

Tavukçuluk işlermelerinde en büyük harcama (\%6070) yem için yapılmaktadır. Ĕger üretici kendi yem hammaddesini kendisi üretir ya da yemini kendisi yapabilirse yem harcamaları düşebilir. Oysa bu çalışma, Hatay ilinde faaliyet gösteren yumurtacı işletmelerin \%86.95 yemi dışarıdan satın aldığını göstermiştir. Üstelik işletmelerin küçük olması ya da maddi kaynağın yetersizliklerinden yemin az miktarlarda ve sürekli değişen fiyatlarla satın alınması yem maliyetinin artmasına neden olmaktadır. Dolayısıyla Hatay ilindeki yumurtacı işletmecilerin en önemli sorununun yem temin edilmesi olduğu düşünülmektedir. Ayrıca işletme sahiplerinin üniform yaprya sahip yarka temini 
konusunda büyük sıkıntı yaşadıkları belirlenmiştir. İşletmelerin kapasitesinin küçük olması yarka üreticilerinin düşük miktarlardaki talepleri önemsememesi, yarka üretim firmaları tarafından gelen sürülerin farklı yaşta ve canlı ağırlıkta olması, yumurta üreticilerine zaman ve para kaybı olarak yansımaktadır. Diğer önemli bir sorun da merdiven altı üreticilerin yumurta satış fiyatlarının oluşmasında üretici aleyhine rol oynamasıdır. Özellikle küçük işletmecileri daha çok mağdur eden bir diğer sorun ise paketleme ve pazarlamadır. Bu işlemi maddi imkansızlıklar ve teknik bilgi yetersizliği nedeniyle gerçekleştiremiyen yumurta üreticileri yumurtaları neredeyse maliyetine aracılara satmak zorunda kalmaktadır.

Sonuç olarak Hatay ili yumurta üreticilerinin sorunlarının çözümü, sektörün korunması ve büyümesinin devam ettirilebilmesi için yem girdisine destekleme yapılmasının yararlı olacağı düşünülmektedir. Homojen yarka temini konusunda büyük sorun yaşayan özellikle küçük işletmelere teknik destek verilebilir. Ayrıca en önemli sorunlardan olan pazarlama konusunda bilgilendirme yapılabilir. Merdiven altı üretiminin durdurulması için ilgili kurumlarca daha sıkı denetimler yapılabilir. Küçük işletmeler bir araya gelerek paketleme ve pazar sorununu çözebilir. Böylece artan kâr oranıyla küçük işletmelerde kapasite artışı sağlabilir. Özellikle Avrupa Birliği başta olmak üzere bazı ülkelerde bazı hastalıklardan (kuş gribi vs) dolayı bu ülkelerde ortaya çıkan yumurta ihtiyacını karşlamaya yönelik üreticilere dış pazara açılma konusunda destek verilebilir.

\section{TEŞEKKÜR}

Bu çalışmaya maddi destek sağlayan Hatay Mustafa Kemal Üniversitesi Bilimsel Araştırma Projeleri Kurum Koordinatörlüğüne (BAP: Proje No: 15960) teşekkür ederiz.

\section{KAYNAKLAR}

Alagöz T 1983. Çukurova Bölgesi Tavukçuluk İşletmelerinde Kümeslerin Durumu, Özellikleri ve Bölge İklim Koşullarına Uygun Kümes Planlarının Geliş̧irilmesi Üzerine Bir Araştırma. Ç.Ü. Fen Bilimleri Ens., Kültürteknik Anabilim Dalı, Doktora Tezi, $126 \mathrm{~s}$.

Anonim 2014. Türlerine Göre Kümes Hayvanları Sayısı, www.tuik.gov.tr. Türkiye İstatistik Kurumu.
Anonim 2018a. Yumurta Tavukçuluğu Verileri 2018. https://www.yum-bir.org/UserFiles/File/yumurtaveriler 2019web.pdf.

Anonim 2018b. Türkiye İstatistik Kurumu Hayvansal Üretim Kayıtları. http://www.tuik.gov.tr/PreTablo Arama.do\%3Fmetod\%3Dsearch.

Anonim 2019a. Yumurta Sektörü. https://www. bantb.org.tr/upload/dosyalar/AB9_yumurtasektoru -2016.pdf (Erişim tarihi: 20.04.2019).

Anonim 2019b. Ziraat Mühendisleri Odası. Yumurta Sektör Raporu. www.zmo.org.tr/resimler/ekler/ 2fdeeed5663ee80_ek.pdf. (Erişim tarihi:01.03. 2019).

Aydın F, Çelen MF 2017. GAP Bölgesi Yumurta Tavukçuluğu Işletmelerinin Demografik ve SosyoEkonomik Yapısı. Batman Üniversitesi Yaşam Bilimleri Dergisi. 7(2): 107-117.

Bayaner A 1999. Çorum İlinde Yumurta Tavukçuluğunun Ekonomik Analizi. Tarımsal Araştırma Ekonomisi Enstitüsü (TEAE). Yayın No: 23, Ankara, 88s.

Çicek H, Gunlu A, Tandogan M 2008. The Factors Affecting Profitability in Layer Hen Enterprises in Southern West Region of Turkey. Journal of Food. Agriculture \& Environment, 6(2): 286-289.

Cönk E 2006. Afyonkarahisar İli Merkez Ilçe Yumurta Tavukçuluğu Işletmelerinin Yapısal Özellikleri ve Işletmelerde Karşılaşılan Sorunlar. Afyon Kocatepe Üniversitesi Sağllk Bilimleri Ens., Zootekni ve Hayvan Besleme Ana Bilim Dalı, Yüksek Lisans Tezi, $22 \mathrm{~s}$.

Demircan V, Yılmaz H, Dernek Z, Bal T, Gül M, Koknaroglu H 2010. Economic Analysis of Different Laying Hen Farm Capacities in Turkey. Agric. Econ. - Czech. 56(10): 489-497.

Efil H, Sarıca M, Öz H 1993. Çorum Yöresi Tavukçuluk İşletmelerinin Yapısal Özellikleri, Ekonomik Durumları, Sorunlar ve Çözüm Yollarının Araştırılması. TKB TAGEM Karadeniz Tarımsal Araştırma Ens., Yayın No: 7 Samsun.

Eleroğlu H, Yıldırım A, Toker T 2004. Sivas İlinde Tavukçuluğun Durumu 4. Ulusal Zootekni Bilim Kongresi 01-03 Eylül, Isparta.

Köse B, Durmuş İ 2014. Ordu Ilindeki Tavukçuluk Işletmelerinin Genel Yapısı, Sorunları ve Çözüm Önerileri. Akademik Ziraat Dergisi, 3 (2): 89-94.

Şahin A, Yıldırım İ 2001.Van Ilinde Yumurta Tavukçuluğu Yapan Işletmelerin Ekonomik Analizi. Yüzüncü Yıl Üniversitesi. Ziraat Fakültesi. Tarım Bilimleri Dergisi. 11 (2):57-66. 